\title{
PERBEDAAN PENGARUH ANTARA PENGGUNAAN ABM KRUK DENGAN PROSTESIS TERHADAP MOBILITAS PASIEN PASCA AMPUTASI TRANSTIBIAL
}

\author{
Yopi Harwinanda Ardesa, Cica Tri Mandasari Ningsih, \\ Muhammad Syaifuddin \\ Poltekkes Kemenkes Surakarta Jurusan Ortotik Prostetik
}

\begin{abstract}
Background: To know the difference between using crutches utch and prosthesis on patient mobility after transtibial amputation, Research Design is type of preexperimental study with static comparation group research design. The subjects of this study were transtibial amputation patients divided into two groups. Each group consists of 15 people. Methods: Type of group in this study is a paired group in which one person gets two treatments. PT Kuspito Ortotik Prostetik Karanganyar, Time: June to October 2017 . One person gets two treatments in the form of Kruk and prosthesis, prosthesis user will be tested with AMPpro test and Kruk user usage will be tested using AMPnopro, Measurements: AMPpro 20 test and AMPnopro 21 test, different test with Wilcoxon Signed Ranks Test. Results: Showed an average balance in the crutches group $(15,32)$ while the mean balance was in the prosthesis group $(45,38)$. The result of statistical test with man whitney shows $p$ value 0,000 <0,05 so there is difference of effect of crutch and prosthesis on patient mobility after transtibial amputation. Conclusion: The results of this study indicate that there is a difference between the use of Kruk and the prosthesis of mobility, the mobility of the prosthesis user has a higher level at the level of $k-4$, while the Kruk level is the $k-3$ level.
\end{abstract}

Keywords: Crutches, Prostheses, Mobility, Transtibial Amputations

\section{PENDAHULUAN}

Hilangnya sebagian alat gerak akan menyebabkan ketidakmampuan seseorang dalam derajat yang bervariasi, tergantung dari luas hilangnya alat gerak, usia pasien, ketepatan operasi dan management pasca operasi. salah satu faktor ini bertanggung jawab atas kondisi ketdakmampuan pasien untuk kembai ke kemampuan funsional seperti sebelumnya. Berdasarkan penelitian saat ini amputasi pada anggota gerak bawah mencapai 85\%-90\% dari seluruh amputasi dan amputasi bawah lutut (transtibial amputation) merupakan jenis operasi amputasi yang sering dilakukan (vitriana, 2002).

Dari data WHO, Penyebab amputasi sangat bervariasi di seluruh di dunia, 3 penyebab utama adalah diseas, trauma dan conginetal deformitas. Disease dan trauma merupakan penyebab utama amputasi, 30\% kasus amputasi disebabkan oleh trauma. Suatu negara dengan sejarah perang atau negara konflik $80 \%$ amputasi disebabkan oleh tauma. negara industri seperti USA dan Denmark sekitar $65 \%$ amputasi disebabkan karena disease. Disease yang sering terjadi adalah vascular disease, diabetes juga termasuk disease yang banyak terjadi karena 
terdapat sekitar 135 juta orang penderita diabetes di seluruh dunia. Conginetal amputation merupakan penyebab yang paling sedikit, terdapat sekitar $3 \%$ amputasi conginetal (WHO, 2004).

Amputasi bawah lutut tidak hanya memberikan efek pada kemampuan berjalan, tapi juga mempunyi dampak terhadap tingkat partisipasi seseorang dalam aktivitas sosial di masyarakat, prespektif atau pandangan masyarakat dan kualitas hidup. bagaimanapun juga tingkat kualiitas hidup setelah amputasi berhubungan erat dengan mobilitas dan kemampuan berjalan. Maka dari itu tujuan utama dari proses rehabilitasi medis adalah meningkatkan status fungsional, meningkatkan mobilitas atau ambulasi dan meningkatkan kualitas hidup. Dalam proses rehabilitasi pasien amputasi, dengan meningkatkan mobilitas pasien amputasi dapat dibantu menggunakan alat bantu mobilitas dan prostesis (velzen,2006).

Salah satu alat bantu mobilitas yang sering dipakai pasien amputasi adalah kruk. sangat penting bagi orang dengan disabilitas untuk bisa nyaman menggunakan kruk dengan rasa nyaman maka fungsi kruk bisa maksimal. penggunaan kruk sangat membantu para disabilitas untuk bergerak lebih mobile sehingga dapat melakukan berbagai aktivitas dengan nyaman. Keuntungan lain dari kruk adalah bisa digunakan untuk banyak individu dengan kondisi amputasi, paraplegia, patah tulang, orang cidera ligamen dan lain - lain (Shorthel, 2001)

Alat mobilitas lain yang dapat digunakan adalah prostesis, Prostesis adalah suatu alat pengganti bagian tubuh yang hilang. Prostesis ini mengganti fungsi yang sangat komplek dari anggota gerak. fungsi utama prostesis adalah untuk membantu ambulasi atau mobilitas disbilitas pada kegiatan sehari -hari. Sekitar 84 - $95 \%$ pasien amputasi menggunakan prostesis hampir setiap hari tapi pada lansia, mereka tidak dapat berjalan seaktif pasien amputasi dengan usia muda sehingga para lansia lebih memilih mengunakan alat bantu mobilitas berupa kursi roda sebagai alternatif pilihan (Steward, 2008).

Berdasarkan uraian tersebut di atas, penulis tertarik dengan fungsi dari alat bantu mobilitas kruk dan prosthesis. Maka dari itu peneliti akan mengangkat topik di atas dalam bentuk penelitian dengan judul "Perbandingan antara penggunaan ABM (Alat Bantu Mobilitas) kruk dengan penggunaan prostesis terhadap mobilitas pasien pasca amputasi transtibial". Peneliti mengambil tempat penelitian di daerah Karanganyar, dikarenakan terdapat beberapa klinik Ortotik Prostetik di kabupaten karanganyar, dan juga pendidikan Ortotik prostetik yang bertempat di karanganyar, sehingga peneliti bisa mengambil sampel dari pasien pembelajaran di Kampus Ortotik Prostetik.

Mobilitas atau mobilisasi merupakan kemampuan individu untuk bergerak secara bebas, mudah dan teratur dengan tujuan untuk memenuhi kebutuhan aktivitas guna mempertahankan kesehatannya (Aziz, 2006). Sehingga, mobilitas adalah suatu usaha untuk berpindah atau bergerak dengan menggunakan kemampuan fisik guna untuk melakukan aktivitas sehari-hari.

Mobilisasi diperlukan untuk meningkatkan kemandirian diri, meningkatkan kesehatan, memperlambat proses penyakit khususnya penyakit degenerative, dan untuk aktualisasi diri (Murbarak, 2008). Tujuan mobilitas yaitu 
(1) memenuhi kebutuhan dasar manusia,

(2) mencegah terjadinya trauma,(3) mempertahankan tingkat kesehatan, (4) mempertahankan interaksi sosial dan peran sehari - hari, (5) mencegah hilangnya kemampuan fungsi tubuh.

Alat Bantu Mobilitas adalah suatu alat yang dibuat untuk membantu seseorang dalam meningkatkan fungsional anggota gerak tubuh yang mengalami gangguan agar menjadi lebih baik dan lebih mandiri. Alat bantu mobilitas dapat dengan mudah dan praktis digunakan sehari - hari dalam fungsi mobilitas. Alat bantu mobilitas memunyai fungsi yaitu (1) sebagi kompensasi untuk kondisi tertentu, (2) membantu individu yang mempunya gangguan keseimbangan dan kesetabilan,

(3) memberi support pada kondisi kekuatan dan kemampuan tubuh yang menggalami penurunan, mengakomodasi seseorang dengan koordinasi yang buruk, (5) membantu mobiitas pasien amputasi anggota gerak bawah dan (6) rellief, untuk kondisi individu yang sakit saat menumpu dan kondisi fraktur (Department of Vermont Health Access, 2014).

Kruk merupakan salah satu alat bantu mobilitas atau alat bantu jalan, tidak hanya memberikan keuntungan tetapi juga menyisakan permasalahan atau efek negatif, seperti kurang nyaman saat digunakan oleh pengguna dan peningkatan resiko cedera. Shabas dan Scheiber (1986) menjelaskan kasus yang dijumpai pemakai kruk yang ukurannya tidak pas dan letak penekanan pada bahu yang berlebihan, disertai dengan ayunan kruk yang berlebihan pada saat pemakaian akan meningkatkan resiko terjadinya cedera bahu. Cedera bahu akan menyebabkan efek seperti kesulitan mengangkat lengan ke atas dan kelemahan rotasi eksternal pada tangan (Shabas dan Scheiber, 1986). Indikasi penggunaan kruk yaitu (1) dapat berjalan tetapi merasa kurang stabil dan membutuhkan bantuan, (2) fungsi arm, shoulder dan tangan masih baik, (3) seseorang yang kehilangan salah satu anggota gerak bawah atau keduanya, dan (4) individu yang mempunyai kondisi dimana diharuskan untuk non weight bearing pada anggota gerak bawah, misalnya fraktur pada lower limb, post operasi, cidera dan lain-lain ( National Multiple Sclerosis Society, 2005).

Kelebihan penggunaan kruk yaitu (1) memberi kestabilan saat berjalan, (2) membuat base of support lebih lebar saat berjalan, sehingga mengurangi resiko jatuh, (3) offload body weight saat berjalan atau beraktivitas, dan (4) tinggi kruk dapat di sesuaikan ( National Multiple Sclerosis Society, 2005).

Kekurangan penggunaan kruk yaitu (1) jika ukuran tidak tepat maka akan menimbulkan masalah pada wrist, elbow dan shoulder, (2) postur tubuh akan terganggu karena tubuh akan cenderung kedepan saat menggunakan kruk, (3) karena penggunaan kruk di kontrol oleh shoulder dan arm, dan (4) maka pengguna harus mempunyai fungsi lengan yang baik (National Multiple Sclerosis Society, 2005).

\section{METODE PENELITIAN}

Pada penelitian perbedaan pengaruh antara penggunaan ABM kruk dengan penggunaan prostesis terhadap mobilitas pasien pasca amputasi transtibial menggunakan desain penelitian pra-eksperimental dan rancangan penelitian adalah Static Group Comparison. static group comparison merupakan modifikasi dari desain pre and 
post test. Dalam desain ini terdapat dua kelompok yang dipilih sebagai objek penelitian. Kelompok pertama dan kedua mendapatkan perlakuan dan kelompok kedua berfungsi sebagai kelompok pembanding. pengukuran efektivitas perlakuan adalah hasil penilaian kelompok pertama dibandingkan dengan penilaian kelompok pembanding. Pada penelitian ini kelompok pertama di beri perlakuan berupa ABM kruk dan di ukur dengan instrumen alat ukur AMPnopro, kemudian kelompok kedua sebagi pembanding menggunakan prostesis yang di ukur dengan instrumen alat ukur AMPpro dan kedua hasil perlakuan tersebut di bandingkan hasilnya.

\section{Lokasi dan Waktu Penelitian}

Penelitian ini dilakukan di PT Kuspito Ortotik Prostetik Karanganyar, waktu pada bulan Juni s/d Oktober 2017. Populasi yang diambil peneliti adalah semua pasien amputasi transtibial di PT Kuspito Ortotik Prostetik Karanganyar.

\section{Alat Ukur Penelitian}

Alat ukur untuk penelitian ini adalah AMPpro (amputee mobility predictor with prosthesis) dan AMPnopro (amputee mobility predictor without prosthesis), alat ukur ini berupa 21 test padaAMPpro dan 20 test pada AMPnopro yang dapat menjadi ukuran tingkat mobiitas dan fungsional prosthesis maupun alat bantu mobilitas. Test ini di rancang untuk mengukur kemampuan fungsional pasien tanpa menggunakan prosthesis dan menggunakan prosthesis. Test yang di terapkan pada AMPpro dan AMPnopro sama Cuma terdapat 1 test yang tidak bisa diterapkan pada pasien ketika tanpa menggunakan prosthesis, sehingga test yang di terapkan AMPnopro menjadi 20 test. Hasil test berupa skor, untuk masing- masing test mempunyai skor antara $0,1,2,3,4,5$ dan hasil total dari skor dapat di katogorikan menurut klasifikasi MFCL, klasifikasi MFCL adalah klasifikasi 5 level fungsional untuk mendeskripsikan kemampuan fungsional seseorang yang mengalami amputasi transtibial( Gailey, 2002).

\section{Berikut klasifikasi MFCL :}

K-level Tidak mempunyai kemampuan 0 atau potensial untuk ambulasi, berpindah secara aman dengan atau tanpa bantuan dan prostesis tidak dapat meningkatkan kualitas hidup atau mobilitasnya.

K-level Mempunyai kemampuan atau 1 potensial untuk menggunakan prostesis untuk berpindah atau ambulasi pada kondisi permukaan yang stabil.

K-level Mempunyai kemampuan atau 2 potensi untuk ambulasi pada lingkungan dengan rintangan pada level ringan seperti tangga, permukaan tanah yang tidak rata dan rintangan.tipe komunitas yang memiliki keterbatasan ambulasi.

K-level Mempunyai kemampuan atau 3 potensi untuk ambulasi dengan kondisi yang berubah-ubah. Tipe dari komunitas amputee yang mempunyai kemampuan pada lingkungan yang cukup banyak halangan dan mungkin membutuhkan bimbingan, latihan dan terapi yang diperlukan untuk penggunaan prosthesis.

K-level Mempunyai kemampuan dan 4 potensial untuk ambulasi 
menggunakan prostesis yang melebihi skil kemampuan dasar mobilitas, yang memperihatkan pengaruh yang besar, tekanan, atau level energi. Tipikal ini di jumpai pada anak, pasien dewasa yang aktif atau atlet.

Kruk adalah salah satu alat mobilitas dasar yang digunakan pasien pasca amputasi untuk melakukan mobilitas sehari-hari. Dalam penelitian ini akan diteliti seberapa besar ingkat mobilitas pasien pasca amputasi bawah lutut yang menggunakan ABM kruk dengan diukur menggunakan instrumen ukur mobilitas yaitu AMPnopro yang di dalamnya terdapat beberapa test yang meliputi test kemampuan keseimbangan statis, dinamis dan ambulasi yang merupakan unsur dasar mobilitas dan hasil dari test tersebut berupa data numerik yang dapat dikonversi dalam kategori level fungsional mobbiitas (k-level).

Mobilitas pengguna prostesis pada pasien amputasi transtibial

Prostesis adalah salah satu alat bantu pengganti anggota gerak tubuh yang hilang yang mana sangat membantu pengguna dalam mobilitasnya. fungsi prostesis adalah selain pengganti anggota gerak juga sebagai pengganti fungsi anggota gerak yang hilang maka fungsi peranan prostesis sangat berpengaruh dalam tingkat mobilitas pasien pasca amputasi transtibial. Tingkat mobiitas menggunakan prostesis dapat di ukur dengan instrumen alat ukur AMPpro yang di dalamnya terdiri test mobilitas test kemampuan keseimbangan statis, dinamis dan ambulasi ynag merupakan unsur dasar mobilitas dan hasil dari test tersebut berupa data numerik yang dapat dikonversi dalam kategori level fungsional mobbiitas (k-level).

\section{HASIL PENELITIAN}

Perbedaan Pengaruh Antara Penggunaan Abm Kruk Dengan Prostesis Terhadap Mobilitas Pasien Pasca Amputasi Transtibial

Hasil uji normalitas dengan shapiro wilk diketahui bahwa nilai $p$ value mobilitas pasien sebesar $0,001<0,05$ sehingga data tidak normal maka digunakan statistik non parametrik yaitu uji man whitney. Hasil penelitian perbedaan pengaruh penggunaan kruk dan prostesis terhadap mobilitas pasien pasca amputasi transtibial dapat dilihat pada tabel berikut :

Tabel 1. Perbedaan Pengaruh Antara Penggunaan ABM Kruk Dengan Prostesis Terhadap Mobilitas Pasien Pasca Amputasi Transtibial

\begin{tabular}{llccc}
\hline Variabel & Perlakuan & Mean & $\mathrm{Z}$ & $\begin{array}{c}p \\
\text { value }\end{array}$ \\
\hline Mobilitas & Prostesis & 45,38 & - & 0,000 \\
pasien & Kruk & 15,32 & 6,63 & \\
\hline
\end{tabular}

Hasil penelitian menunjukkan ratarata keseimbangan pada kelompok kruk $(15,32)$ sedangkan rata-rata keseimbangan pada kelompok prosthesis $(45,38)$. Hasil uji statistik dengan man whitney menunjukkan $p$ value $0,000<0,05$ sehingga terdapat perbedaan pengaruh penggunaan kruk dan prostesis terhadap mobilitas pasien pasca amputasi transtibial.

\section{PEMBAHASAN}

Hasil penelitian menunjukkan bahwa terdapat perbedaan pengaruh penggunaan kruk dengan prosthesis pada mobilitas pasien pasca amputasi transtibial $(0,000<0,05)$, hal ini juga diketahui 
bahwa rata-rata keseimbangan pada kelompok kruk $(15,32)$ sedangkan ratarata keseimbangan pada kelompok prosthesis $(45,38)$. Hal ini di dukung oleh penelitian sebelumnya dari Aaron Moles (2013) yang menyatakan bahwa instrumen alat ukur Ampro sangat kompitabel dalam menjadi tolak ukur untuk mengukur fungsional mobilitas individu pasca amputasi. Hasil dari penelitian tersebut adalah prosthesis meningkatkan fungsional pasien pasca amputasi dari segi peningkatan mobilitasnya.

Hasil tersebut juga didukung dari teori Sarinem yaitu Gangguan mobilisasi adalah suatu keadaan keterbatasan kemampuan pergerakan fisik secara mandiri yang dialami oleh seseorang (Sarinem, 2010). Teori tersebut menguraiakan tentang berbagai permasalahan yang dihadapi oleh penyandang disabilitas fisik. Disabilitas fisik yang di alami seseorang dapat mengakibatkan gangguan kemampuan fisik untuk melakukan suatu perbuatan atau gerakan tertentu berhubungan dengan kegiatan hidup sehari-hari. Keterbatasan fisik menyebabkan tidak dimilikinya ketrampilan kerja (produksi). Hal ini menyebabkan rendahnya pendapatan dan berada di bawah aris kemiskinan. Secara sosial, disabilitas fisik mempengaruhi ketidakmampuan hubungan dalam mengambil peranan dalam kegiatan sosial atau kelompok, kecanggungan hubungan antar manusia dimasyarakat, dan ketidakmampuan saling pengaruhmempengaruhi dalam suatu kelompok sosial atau interaksi sosial. Sehingga diperlukan alat bantu untuk bisa melakukan mobilitas dengan baik.

Transtibial prosthesis itu sendiri merupakan salah satu jenis prostesis anggota gerak bawah yang didesain untuk mengganti anggota gerak tubuh yang hilang tepatnya pada bawah lutut, sehingga seseorang yang kehilangan anggota gerak bawah dapat kembali berjalan dengan menggunakan transtibial prostesis.

\section{KESIMPULAN DAN SARAN}

1. Hasil penelitian menunjukkan bahwa terdapat perbedaan pengaruh penggunaan kruk dengan prosthesis pada mobilitas pasien pasca amputasi transtibial $(0,000<0,05)$

2. Hal ini juga diketahui bahwa ratarata keseimbangan pada kelompok kruk $(15,32)$ sedangkan rata-rata keseimbangan pada kelompok prosthesis $(45,38)$. Disimpulkan bahwa penggunaan prostesis pada pasien amputasi transtibial mempunyai keseimbangan yang lebih baik dibanding penggunaan ABM Kruk.

Saran yang dapat diberikan antara lain adalah sebagai berikut :

1. Bagi masyarakat.

Bagi difabel amputasi transtibial dan keluarganya perlu meningkatkan pemahaman tentang himbauan tindakan rehabilitasi pada amputasi transtibial yang baik dan benar dalam pandangan medis sehingga dapat mengembalikan fungsi berjalan secara maksimal dan tidak menimbulkan secondary deformity

2. Bagi Institusi Pendidikan

Institusi pendidikan hendaknya berperan untuk memberikan edukasi dan meningkatkan pengetahuan masyarakat tentang peran dan manfaat ortotik prostetik perlu terus ditingkatkan melalui pemberian konsultasi ataupun mengadakan seminar kesehatan.

3. Bagi Praktisi Ortotis Prostetiis 
Praktisi hendaknya terus mengadakan inovasi dengan melakukan penelitian tentang manfaat, kelebihan dan kekurangan dari bahan-bahan yang dipilih untuk mengembangkan pengetahuan ortotik prostetik dan pelayanan ortotik prostetik di masyarakat.

\section{DAFTAR RUJUKAN}

Alimul H., A. Aziz. 2006; Pengantar Kebutuhan Dasar ManusiaAplikasi Konsep dan Proses Keperawatan, 1. Jakarta: Salemba Medika

Dahlan, S., 2004; statitiska untuk kedokteran dan kesehatan; seri 1, arkans, jakarta, hal 68-72

Department of Vermont Health Access, 2014 ; Ambulatory Assistive Devices, diakses tanggal 10/11/2015, dari www.dvha.vermont.gov

Kaluf, B.d., 2014; evaluation of amputee mobility through routine adoption of amp and peq-ms in clinical practice: initial 6 month retrospective chart review; diakses tanggal 10/10/2015, dari http://www.oandp.org/

publications/jop/2014/2014-35.pdf

National multiple sclerosis society, 2005; How to Choose the Mobility Device that is Right for You; diakses tanggal 21/ 10/2015, dari http://www.nationalmssociety.org/

Rostiana \& Damayanti, S. 2003; Dinamika emosi penyandang tunadaksa pasca kecelakaan. Jurnal Psikologi Arkhe, edisi 1, hal 1528.

Shortell,D., Kucer,J., Neeley, W,L., \& Leblanc, M. 2001; The design ofa compliant composite crutch.
Journal of rehabilitation research and development,38 (1). Hal 2332.

Smith, D,G., 2003; transtibial amputations successes and challenges, diakses tanggal 8/5/205, dari http://www.amputee-coalition.org/

Smith, D,G., 2009; $\quad$ Transtibial Amputation General Principles \& The Extended Posterior Flap Technique, diakses tanggal 7/12/2015, dari http://www.ispo.nl/

Stewart.,2008; Lower Limb Amputation; diakses tanggal 4/8/2015, dari https://www.gov.uk/government/u ploads/system/uploads/attachment _data/file/384461/amputations_lo wer_limb.pdf

Sugiyono, 2008; Metode Penelitian $\underline{\text { Kunatitatif Kualitatif dan R\&D, Bandung }}$ Alfabeta.

Velzen, V, 2006; Physical capacity and walking ability after lower limb amputation: a systematic review; diakses tanggal 6/8/2015, http://dspace.ubvu.vu.nl/

Vitriana., 2002; rehabilitasi pasien amputasi bawah lutut dengan menggunakan immediate post operative prosthetic; diakses tanggal 5/8/2015, dari http://pustaka.unpad.ac.id/

WHO. 2004; "The Rehabilitation of People with Amputations". Diakses tanggal 26/5/2015, dari http://www.posna.org/.

Wilson, B., 1970; Artificial Limbs, No 1, Vol 14, hal.1 